will include Dr. Stella Churchill, Dr. Robert Edbrooke, Mr. R. Makinnon Wood and Dr. L. A. Rawlings. It is hoped that there will be a full discussion of the whole subject, and particularly of the attitude which the medical profession might reasonably adopt towards it. Information about the Medical Peace Association may be obtained from the Hon. Secretary, Dr. Cecile Booysen, 12 Kent Terrace, N.W.1.

\section{Nutrition in the Colonial Empire}

THE Prime Minister has appointed a Committeo of the Economic Advisory Council with the following terms of reference: "(1) To survey the present state of knowledge in regard to nutrition in the Colonial Empire in the light of the replies received to the circular dispatch addressed by the Secretary of State for the Colonies on April 18, 1936, to the Officers Administering the Governments of Colonial Dependencies. (2) To advise from time to time as to the measures calculated to promote the discovery and application of knowledge in this field." The Committee is constituted as follows : Earl De La Warr (chairman), Prof. E. P. Cathcart, Mr. G. L. M. Clauson, Dr. Philippa C. Esdaile, Prof. Noel Hall, Dr. J. M. Hamill, Mr. Francis Hemming, Mr. E. M. H. Lloyd, Prof. Edward Mellanby, Sir John Orr, Dr. Audrey Richards, Mr. H. S. Scott, Sir Thomas Stanton, Mr. F. A. Stockdale, Mr. Hans Vischer. The secretaries to the Committee are Mr. D. H. F. Rickett (Economic Advisory Council) and Mr. C. G. Eastwood (Colonial Office).

\section{Announcements}

Mme. JoLIot-CURre has resigned her appointment of Under-Secretary for Scientific Investigation in the French Cabinet to occupy a chair in the Faculty of Natural Science at the Sorbonne, and has been succeeded by Prof. M. Jean Perrin, For.Mem.R.S., known for his work on atomic chemistry, and Nobel prizeman for physics in 1926.

Dr. Wolfand Heubner, professor of pharmacology at the University of Berlin, has been elected an honorary member of the Biological Society of Vienna and of the Imperial Leopold Caroline German Academy of Natural Philosophers at Halle.

Prof. Ferdinand Hueppe, of Dresden, emeritus professor of hygiene in the German University at Prague, has been awarded the Goethe Medal for Science and Art by the Chancellor of the Reich in recognition of his services in connexion with physical training.

AT the thirty-ninth Congress of the International Law Association for the Protection of the Civilian Population against Modern Warfare, recently held in the Cour de Cassation of the Paris Palais de Justice, a committee was formed to consider the question of the protection of the civilian population against the new engines of warfare, and especially aerial bombardment. The work of the Committee will be carried on in close association with the International Committee of the Red Cross and the International Association for the Protection of Humanity recently founded at Monaco.

Advisory Leaflet No. 272 of the Ministry of Agriculture directs attention to the disease fowl paralysis, which is unfortunately becoming more common. The cause is not known, and no treatment of proved value is available, but the disease can be minimized by removing weak birds, and by not breeding from infected stocks.

Cultivation and distillation of peppermint form the subject of Advisory Leaflet No. $\mathbf{9 8}$ of the Ministry of Agriculture. Two varieties of this fragrant herb are recognized, namely, black mint, Mentha piperata var. officinalis, and white mint, $M$. piperata var. vulgaris. Harvesting and distilling are described in detail, and the effects of the fungus disease, Puccinia menthce, are considered. Peppermint might be grown with advantage on a larger scale in Great Britain.

THE resumption of work in the technicel schools and eolleges gives special value to the issue of Foyle's Technical Catalogue (London: W. and G. Foyle, Ltd.) which contains particulars of new and second-hand books on more than 450 subjects coming within the range of applied science.

THE latest catalogue of old scientific books issued by E. P. Goldschmidt and Co., Ltd., of Bond Street, W.1 (No. 40. Old Science and Medicine) includes 216 items, many of great interest, on a variety of subjects, and contains a number of facsimile and other illustra. tions. Among the books offered for sale are copies of the first edition of Gilbert's "De Magnete", and of an edition of this work printed at Stettin in 1633.

Applications are invited for the following appointments, on or before the dates mentioned :

Assistants, Grade II and III (engineering) in the Admiralty Technical Pool-The Secretary of the Admiralty (C.E. Branch), Whitehall, London, S.W.1 (November 2).

A heating and ventilating engineer in the Directorate of Works and Buildings of the Air MinistryThe Secretary (W.B. 9), Air Ministry, Adastral House, Kingsway, W.C.2 (November 14).

A research assistant in the Department of Oil Engineering and Refining, University of Birmingham -The Secretary (November 18).

A junior lecturer in civil engineering in the Uni. versity of the Witwatersrand-The Secretary, Office of the High Commissioner for the Union of South Africa, South Africa House, Trafalgar Square, London, W.C.2 (December 2).

Structural engineering assistants in the Designs Branch of the Directorate of Fortifications and Works at the War Office-The Under-Secretary of State (C.5), The War Office, London, S.W.1 (Quote Appts. (2).

An acting editor to the Royal Scottish Geographical Society-The Secretary, Synod Hall, Edinburgh. 